\title{
Impact of New Forest policies on Collection and Marketing of Minor Forest Produce in Karnataka, with Special reference to LAMPS
}

\author{
Shivaprasad TM* and Dr. H.M Chandrashekar** \\ * Research Scholar, Agri-Business Management, Institute of Development Studies, University of Mysore, \\ Manasagangotri, Mysore-570006, Karnataka State. \\ ** Asst. Professor, Agri-Business Management, Institute of Development Studies, University of Mysore, \\ Manasagangotri, Mysore-570006, Karnataka State.
}

\begin{abstract}
There has been increasing trends in the trade of forest products particularly Non Timber Forest Products (NTFP). Increasing trade of forest products has supported economic growth of a number of emerging countries. There is strong evidence that forest products play a significant role in the livelihoods of the rural poor. Forest products are the main sources of income for the tribal population of many countries. In India the central government came with legislation named as The scheduled tribes and other traditional forest dwellers (Recognition of Forest Rights) Act 2006 popularly known as Forest Rights Act (FRA) 2006 to recognize the tenure and occupational rights of forest dwellers. The forest rights act was the first act enacted in independent Indian that addressed the question of community ownership of MFP and rights and management/governance of forest at the legislative level. The present study is based on primary and secondary data related to collection and marketing of Minor Forest Produce through LAMPS and dependency of Tribal population on Minor forest Products. The study intended to understand the collection and marketing status of MFP in LAMPS and how new forest policies impact on the collection and marketing of MFP's in LAMP Societies.
\end{abstract}

Keywords: Non Timber Forest Products, Forest Right Act, Large sized Adivasi Multi Purpose Societies, Minor Forest Products, Joint Forest Management, Community forest Management

\section{Introduction}

"Forest Produce" is defined as "All material yielded by a forest estate". Forest produce was further classified as "Major Forest Produce" and "Minor Forest Produce". Major forest produce referred to timber, small wood and firewood and minor forest produce referred to all forest produce other than major forest produce including grass, fruit, leaves, animal products, soil and minerals Minor Forest Produce (MFPs) contributes over 50 per cent of the forest revenue and 70 per cent of the export income.

\section{Classification of Non- Timber Forest Produce (NTFPs)}

Non- Timber Forest Produce (NTFPs) also known as minor forest produces (MFP), Minor Forest Produce are classified as follows.

$\begin{array}{ll}\text { Group I } & \text { 1 Minor Forest Produce of plant origin } \\ & 2 \text { Minor Forest Produce of animal origin } \\ \text { Group II } & 3 \text { Minor Forest Produce of mineral origin } \\ \text { Group I } & \text { Tourism, Recreation and wildlife }\end{array}$

1. Minor Forest Produce of plant origin namely edible plant products, spices and condiments, medicinal plants, aromatic plants, fatty oil yield plants, gum and resin excluding plants, tan yield plants, dye oil colour yield plants, fibre and floss yield plants, bamboo canes, fodder and forage, fuel wood, charcoal making, bidi wrapper leaves, other leaves for plates, saponin and marking nut plant and others.

2. Minor Forest Produce of animal origin includes, honey and bees, wax lac and shellac, tussar and other silk insects, animal hides, skins and feathers, horns, bones, ivory and musk.

3. Minor Forest Produce of mineral origin includes mica, sanol, gravel and other minerals.

\section{Group II}

It includes services such as tourism, recreation and wildlife. 


\section{Status Of Forest Products Production And Trade}

Forests around the world provide variety of valuable products aside from the timber. The world's total forest area is just over 4 billion hectares (corresponding to 0.6 ha per capita), which includes Primary forests (36 percent of forest area), Plantation forests (7 percent of total forest area) and other naturally regenerated forests (57 percent). The forests designated for the conservation of biological diversity account for 12 percent of the total forest area or more than 460 million hectares. Around 1.2 billion hectares of forest are managed primarily for the production of wood and non-wood forest products, which is 30 percent of world's forests. An additional 949 million hectares (24 percent) are designated for multiple uses - in most cases including the production of wood and non-wood forest products. Globally, 4 percent of the world's forests are designated for the provision of social services (FRA, 2010)

\section{Production And Trade Of Non-Timber Forest Products In India}

In India, out of the total land area of 329 million ha, only 78.29 million ha are classified as forests. This represents only 23.81 percent of the total geographic area as against the recommended forest coverage of 33 percent. Total growing stock of India' forests and trees outside forest is estimated as $6047.15 \mathrm{~m}$ cum. The annual estimated production of wood and fuel wood from forests is estimated to be as $3.175 \mathrm{~m}$ cum and $1.23 \mathrm{~m}$ tones.

India's rich biodiversity of 45,000 plant species is spread across 16 Agro-climatic zones. Out of these, about 3000 NTFPS species yield are found but only 126 have developed marketability (Maithani 1994; FAO 2002; FAO, 2005). These include medicinal plants, edible plants, starches, gums and mucilage's, oils \& fats, resins \& oleo-resins, essential oils, spices, drugs, tannins, insecticides, natural dyes, bamboos \& canes, fibres \& flosses, grasses, tendu leaves, animal products and edible products.

In India over 50 million people are dependent on NTFPs for their subsistence and cash income. India also has a 42 percent share of total removals in the category of other plant products, such as tendu leaves and lac, followed by Brazil and Mexico (FRA, 2005). Minor forest products contribute about 50 percent to Indian government forest revenue and 70 percent of forest-based product exports. The monetary value of Medicinal and aromatic related global trade is over 60 billion USD; about 70 percent of the NTFPS collection in India takes place in the tribal belt of the country. Around 55 percent of employment in forestry sector is attributed to the sector alone. In the case of Gujarat, the contribution of NTFPs to the total households' income varied from 20.1 percent to 34.1 percent while in the case of West Bengal, it ranged from 26.5 to 55.5 percent. One another study highlighted that tendu leaves were estimated to provide employment nearly to 4 million persons annually by way of Bidi (Local cigarette) manufacturing. He observed that forest based enterprises provided up to 50 percent of income for 20 to 30 percent of labour force in India.

Commercial NTFPs are estimated to generate Rs. 3 billion (US\$ 100 million) annually in India. It exports a large number of NTFPS to other countries earning foreign exchange revenue to the tune of Rs. 10 billion (US \$ 384 million) annually (FAO, 1995). India holds monopoly in world trade over some of the NTFPs such as Karaya gum (Sterculia urens), myrobalans (Emblica officinalis, Terminalia chebula), Sandalwood chips and dust (Santalumalbum).

The export of NTFPS has grown by 20-25 percent over the past few years and during 2006-07, India earned Rs 39.7 billion from export of NTFPs and their valued added extracts. Total export value of Ayush and Herbal products from India is estimated as Rs. 764.25 and 570.76 crores respectively during 2009-10.

India stands at third position with a share of about 16 percent in essential oil trade. Indian Production of the essential oils is estimated to be 17000 tonnes valued about US\$ 195 million. India produces 20000 tonnes of exudates gums in which gum karaya alone contributes about 15000 tonnes. India earns around Rs. 1200 million by the export of gums. World production of essential oils (excluding turpentine oil) is estimated to be about 105000 tonnes to the tune of US\$922 million. The total value of non-timber goods and services available from tropical deciduous forests in India was estimated from a minimum of $\$ 219$ to a maximum of $\$ 357$ per hectare annually.

The contribution of NTFPs and eco- tourism to the Forestry Sectors gross value (of Rs 259.85

Billion) is 16 percent. All India average value of NTFPs to be Rs 1671.54 per hectare and Rs. 41.89 billions as the estimate of gross value of NTFPs 
Impact of New Forest policies on Collection and Marketing of Minor Forest Produce in Karnataka,

IV. Status Of NTFP In Karnataka

The major types of NTFPs harvested in Karnataka as follows

\begin{tabular}{|c|c|c|c|c|c|}
\hline \multirow[b]{2}{*}{ NTFPs } & \multirow[b]{2}{*}{ Unit } & \multicolumn{4}{|c|}{ Quantity in quintals } \\
\hline & & $2005-06$ & 2006-07 & 2007-08 & 2008-09 \\
\hline Charcol & MT & 7425 & 0.5 & & \\
\hline Honey & MT & 55.84 & 1043.67 & 1181.32 & 66.94 \\
\hline Tamarind & MT & 1742.4 & 9081.4 & 185.02 & 1255.53 \\
\hline Seegekai & MT & 746.16 & 506.31 & 805.28 & 594.89 \\
\hline Cashewnut & MT & 123.85 & 538.2 & 31.51 & 87.11 \\
\hline Alalekai & MT & 714.92 & 418.94 & 391.4 & 320.3 \\
\hline Gum & MT & 171.98 & 9.8 & 2 & \\
\hline Canes & MT & 136540 & 121700 & & \\
\hline Uppige & MT & 1469.1 & 2447.23 & 591.63 & 988.74 \\
\hline Dalchinni & MT & 2475.81 & 884.99 & 1032.34 & $678 . .33$ \\
\hline Citradora & MT & 747.7 & 502.76 & & \\
\hline
\end{tabular}

Sources: Forest Sector Report India, 2010.

\section{Forests and Tribals}

Forests have been playing a vital role in the socio-economic and cultural life of the Tribal people of India. These tribal groups inhabit wide ecological and geo-climatic conditions in different concentrations throughout the country. They are homogeneous, culturally firm, have developed strong magico-religious health care systems and wish to retain their distinct life styles.

Tribal livelihood systems vary considerably between different regions as also among various ethnic groups, depending on ecological, historical and cultural factors. These tribal communities which largely occupy the forest regions from time immemorial have lived in isolation from the mainstream of national life but in harmony with nature. They have developed a symbiotic relationship with forests. But the forests in India have suffered over the years due to excessive exploitation and are facing many threats affecting bio-diversity, species composition, forest communities, physiognomy, stratification, vitality, tropic structure, energetic and dynamics as forest resources get depleted, forest communities depending upon them get impoverished. Hence, the preservation of forests is vital for sustaining ecological balance and is the most important factor to protect the environment as well as the forest communities living in and around the forest.

\section{Forest Governance And Implementation Of REDD+ In India}

Forest governance in context to REDD+ is a complex issue as it involves the participation of multiple stakeholders and also holds diversified Interests of individuals and communities across different scales such as local, national, and global, with unbiased decision-making by a group of policy makers, community representatives, government officials, and other experts and practitioners. Forest governance is identified as critical to the success of REDD+. Implementation of robust REDD+ strategy is possible through Community Based Forest Governance.

In India, since the need for fuel wood, timber and other forest products exceeded the country's ability to sustain the quality forest, some major initiatives were taken by the Government of India to improve the structure and functioning of forest governance. The recommendations of the National Commission on Agriculture saw the creation of Forest Corporations for harvesting

forest produce, the establishment of the Indian Institute of Forest Management to produce administrators to manage forest resources as business managers, the initiation of social forestry on village and forest land, the formulation of a National Forest Policy 1988, the creation of a separate Ministry of Environment and Forests, the initiation of Joint Forest Management and the enactment of the Panchayat Raj (extension to Scheduled Areas) Act 1996.

Globally, there is a growing consensus that as a country moves towards full-scale REDD+ implementation, it will need to develop a REDD+ strategy, which would focus on building capacity to create measurable, reportable, and verifiable (MRV) emission reductions and most significantly, establish a robust forest governance mechanism, which will provide a platform for REDD+ readiness. Reducing Emissions from Deforestation and Degradation (REDD + ) is a global mechanism that aims at sustainable forest management (SFM) through protecting forests and enhancing carbon sequestration. Primarily, REDD+ needs to have a carbon trading mechanism that would incentivize initiatives that contribute to reductions in emissions from deforestation and forest degradation or increasing the removals of $\mathrm{CO} 2$ from the atmosphere through forest regeneration and protection. Policies and programmes will also be required to create economic incentives and management capacities to drive those reductions through improvements in forest management that is likely to be possible through Community Based Forest Management. Bilaterally, FRA 2006 has to play a key role in strengthening of community based forest management and in enhancing the income of forest dependent communities. 


\section{Participatory Forest Management In India}

Following the mandate of National Forest Policy, 1988, the Government of India has issued guidelines for regularization of eligible encroachment and conversion of forest villages into revenue villages in 1990 . Consequently, ten states have regularized 367,000-hectare forest land but the process was stopped due to order of Supreme Court by putting ban on de-reservation of forests. Simultaneously, the Government of India initiated the process of people's involvement in the conservation, management and protection of forests with benefit sharing mechanism on the principle of 'Care and Share' through Joint Forest Management (JFM) in 1990, that was so called the "The JFM 1990 Resolution".

Joint Forest Management is a concept of developing partnerships between fringe forest user-groups and the forest department based on mutual trust and jointly defined roles and responsibilities with regard to forest protection and development. In JFM, the user (local communities) and owner (Government) manage the resource and share the cost equally.

The JFM programme is another initiative by the Government of India to involve the forest dwelling communities in the management of forest since 1990 and has been implemented by most State Governments in India.

Absence of clear-cut relationship between JFM committee and the existing village panchayat has made the smooth progress of entire JFM process quite difficult in many places. Because of absence of productive functional relationship between the JFM bodies and the Panchayats in the wake of increased decentralization of powers to the Panchayat Raj Institutions (PRI) through the 73rd Constitutional amendment.

The Ministry of Environment \& Forests, Government of India has sent an advisory to the State Government to place JFMCs under Panchayat Raj Institutions. PRI has the legal backing of the Constitution of India while JFM institution lacks it. Mere advisory from Government of India cannot resolve the conflicts of interests between JFMCs and PRI.

\section{Status Of Joint Forest Management Committees (Jfmcs)}

More than 106000 JFMCs were managing more than 22 million hectare forest with benefit sharing mechanism on the principle of care and share. Currently, more than 118213 JFMCs are managing around 23 million hectares of forest in the country (FRI 2011). The JFMCs are largely involved in the plantation and other forestry activities and getting benefits of wages as workers. The mechanism of benefit sharing of 'minor' and 'major' forest produce has not been translated largely from government circulars to the action

Karnataka follows the legislation under section 31-A of Karnataka Forest Act and rest of the states like Bihar, Chhattisgarh, Madhya Pradesh, Goa, Himachal Pradesh, J\&K, Orissa, Punjab, Rajasthan, West Bengal and Kerala are working under the guidelines notified under JFM.

\section{Community Forest Resource (Cfr)}

As per the provisions of the FRA 2006, the sizable area which is around 35-40 million hectare is likely to fall under the category of Community Forest Resource (CFR) where forest dwelling communities will exercise the community forest rights to protect, regenerate and conserve CFR.. Such forests if managed, protected, and regenerated by the communities would affect the forest governance in these areas, so far done by the State Forest Department.

Potential of CFR areas are likely to overlap with JFM and areas managed by Eco-Development Committees. There is therefore urgent need to think about trajectory of forest governance as a whole and the location of community managed systems within this and their relationship with the forest department and other agencies.

\section{The Scheduled Tribes and Other Traditional Forest Dwellers (Recognition of Forest Rights) Act, 2006}

The enactment of the Scheduled Tribes and Other Traditional Forest Dwellers (Recognition of Forest Rights) Act 2006 popularly known as Forest Rights Act (FRA)2006 further broadened the conflict between JFMCs and GramSabhas by empowering GSs with the ownership of MFP and right to protect, regenerate and conserve Community Forest Resources (CFR). JFMCs and GSs have overlapping jurisdiction on forests. The central government has also issued an advisory to the State governments in 2011 to put the JFMCs under the GramSabhas. GramaSabhas do not have a legal tool for the protection of forests therefore FRA authorizes GramSabhas to take assistance of any government department as Forest Department has powers under Indian Forest Act, 1927 and State Forest Acts. The GS also lack capacity to conserve and manage forests scientifically, in spite of having traditional knowledge only.

Although, FRA 2006 has already empowered community with ownership of MFP but the communities are still, sharing less than $10 \%$ of total turnover of MFP which is in the tune of 27 billion US \$ per annum. 
Impact of New Forest policies on Collection and Marketing of Minor Forest Produce in Karnataka,

Impact of Forest Act 2006 on Tribals and Large scale Adivasi Multi Purpose Societies

The Act basically does two things:

- Grants legal recognition to the rights of traditional forest dwelling communities, partially correcting the injustice caused by the forest laws.

- Makes a beginning towards giving communities and the public a voice in forest and wildlife conservation.

There are two stages to be eligible under this Act. First, everyone has to satisfy two conditions:

1. Primarily residing in forests or forest lands;

2. Depends on forests and forest land for a livelihood (namely "bona fide livelihood needs" means fulfilment of livelihood needs of self and family through exercise of any of the rights specified in sub section (1) of section 3 of the Act and includes sale of surplus produce arising out of exercise of such rights)

Second, you have to prove:

- That the above conditions have been true for 75 years, in which case you are an Other Traditional Forest Dweller (s. 2(o))

OR

- That you are a member of a Scheduled Tribe (s. 2(c)); and

- That you are residing in the area where they are Scheduled (s. 4(1)).

In the latter case you are a Forest Dwelling Scheduled Tribe.

\section{Land Rights}

\section{The Law Recognises Three Types Of Rights:}

No one gets rights to any land that they have not been cultivating prior to December 13, 2005 (see section 4(3)) and that they are not cultivating right now. Those who are cultivating land but don't have document can claim up to 4 hectares, as long as they are cultivating the land themselves for a livelihood (section 3(1) (a) and 4(6)). Those who have a patta or a government lease, but whose land has been illegally taken by the Forest Department or whose land is the subject of a dispute between Forest and Revenue Departments, can claim those lands (see section 3(1)(f) and (g)). The land cannot be sold or transferred to anyone except by inheritance (see section 4(4)).

\section{Use Rights}

The law secondly provides for rights to use and/or collect the following:

a. Minor forest produce like Honey, tendu patta, herbs, medicinal plants etc "that has been traditionally collected (see section 3(1) (c))". This does not include timber.

b. Grazing grounds and water bodies

c. Traditional areas of use by nomadic or pastoralist communities i.e. communities that move with their herds, as opposed to practicing settled agriculture

\section{Right to Protect and Conserve}

For the first time, this law also gives the community the right to protect and manage the forest. Section 3(1) (i) provide a right and a power to conserve community forest resources, while section 5 gives the community a general power to protect wildlife, forests, etc. This is vital for the thousands of village communities who are protecting their forests and wildlife against threats from forest mafias, industries and land grabbers, most of whom operate in connivance with the Forest Department.

The Large-scale Adivasi Multi-Purpose Societies (LAMPS) are cooperative societies set up by the government for integrated tribal development in regions with significant tribal populations; they are generally one per taluka.

There are 23 large sized Adivasi-Multi Purpose Co-operative Societies working in Karnataka State. These societies have been organised with the objective of improving the social and financial conditions of the adivasi by creating platform for Tribals to sell their surplus Minor Forest Produce through LAMP societies.

The Impact of Forest Rights Act 2006 and its amended rules 2012 have given rights to tribals communities to collect the minor forest products which are available in their region with Care and Share formula but today the implementation of Forest Rights Act 2006 and its amended rules 2012 have not fully implemented in Karnataka state, due to this tribal's are facing many restriction from Forest officials on 
collecting of minor forest produces where they are not allowed to enter the forest for collection of minor forest produce.

The successful operation of LAMP societies are entirely depending on active participation of tribal members but today tribal's are not aware of new Act and policies due to their illiteracy they are displacing from forest and operation of LAMP societies are also sluggish today.

\section{Conclusion}

Collection and marketing of minor forest produce are highly influenced by the implementation of Forest Act of 2006. The Forest Act of 2006 and its amendments are not fully aware by the Tribals in the study area and its implications also neglected by the study area till date, whereas lack off policy implication by the state and conflict between forest department and Tribals has increased the gap between them which directly have impact on the collection of minor forest produce in the study area and it will also directly affect the operations of LAMPS which are completely dependent on minor forest products.

\section{References}

[1]. Bharath Kumar L. B. (2010) Impact of Non-Timber Forest Products on Tribal Economy - An Econometric Analysis in Western Ghats of Karnataka. Department of Agricultural Economics, College Of Agriculture, Dharwad, Dharwad - 580 005. 9-12

[2]. Forest governances and implementation of REDD+ in India-The energy and Resources Institute -Ministry of Environment and forest-Government of India

[3]. Forest Rights Act 2010, Ministry of Environment and Forest, Government of India, New Delhi.

[4]. Manmohan yadav and kalpana Basera (2013) Status of Forest Products and production and trade-a working paper Series, Centre for Sustainable Forest Management and Forest Certification, Indian Institute of Forest Management, Bhopal

[5]. Maithani, G.P. 1994. Management perspectives of Minor Forest Produce. MFP News, October-December, 1994.Dehradun.

[6]. National Working Plan Code -2014, Ministry of Environment and Forest, Government of India, New Delhi.

\section{Website accessed}

www.forestrightsact.com

http://agroforestry.net/overstory/overstory55.html

http://www.fao.org/documents/en/detail/200714 on 04.03.2013. 